\title{
Recenzja książki Krystyny Baranowicz, Mój zwiq̨zek z Parkinsonem. Niestety nierozerwalny, Pretekst Agencja Reklamowo-Promocyjna, Łódź 2020, ss. 36, ISBN 978-83-957291-0-2
}

Choroba Parkinsona (Parkinson's disease - PD) to schorzenie neurodegeneracyjne mózgu o idiopatycznej przyczynie. Jego nazwa pochodzi od nazwiska angielskiego lekarza Jamesa Parkinsona, który w 1817 roku jako pierwszy opisał symptomy tej choroby. Charakterystyczne dla PD zmiany w istocie czarnej mózgu manifestują się klinicznymi objawami w postaci spowolnienia ruchowego, drżenia kończyn, sztywności mięśni i zaburzeń równowagi. Mogą im towarzyszyć zaburzenia mowy i głosu (najczęściej jest to dyzartria - nieprawidłowości oddechowo-fonacyjno-artykulacyjno-prozodyczne), a także trudności z połykaniem, gryzieniem i żuciem pokarmów. U części pacjentów pojawiają się wahania nastroju oraz depresja, trudności w zakresie pamięci, uwagi oraz widzenia przestrzennego. W literaturze przedmiotu podkreśla się również obecność u chorych zaburzeń żołądkowo-jelitowych, nieprawidłowości sercowo-naczyniowych oraz problemów urologicznych [por. Poewe, 2008; Gatkowska, 2012; Brabenec i wsp., 2017; Dutkiewicz, Friedman, 2020; Wang i wsp., 2020]. Pacjenci z chorobą Parkinsona wymagają wielospecjalistycznej opieki, przede wszystkim neurologa, fizjoterapeuty, rehabilitanta, ale także logopedy, psychologa, psychiatry, gastrologa, kardiologa czy urologa - w zależności od występujących objawów. Potrzebują wsparcia i zrozumienia ze strony najbliższego otoczenia oraz akceptacji środowiska społecznego.

\footnotetext{
* Uniwersytet Łódzki, Wydział Filologiczny, Instytut Filologii Polskiej i Logopedii, Zakład Dialektologii Polskiej i Logopedii, ul. Pomorska 171/173, 90-236 Łódź, e-mail: ewa.gacka@uni.lodz.pl, ORCID: https://orcid.org/0000-0002-1873-7487.
} 
Publikacja Krystyny Baranowicz pt. Mój związek $z$ Parkinsonem. Niestety nierozerwalny to głos pacjentki zmagającej się od wielu lat $\mathrm{z}$ tą nieuleczalną chorobą. Jak podkreśla autorka, nie jest to typowy poradnik „[...] co i jak robić (wstawać z łóżka, pilnować diety, ćwiczyć itp.)" - to książeczka skierowana do chorych „ku pokrzepieniu serc" (s. 4). Szczególnie przydatna będzie tym wszystkim, którzy znajdują się na początku zmagań z chorobą i myślą, jak odnaleźć się w nowej sytuacji, poradzić sobie z lękiem, rozwiać obawy, dowiedzieć się, skąd czerpać nadzieję. Pokrzepiająca i dodająca otuchy jest już sama okładka $z$ bukietem czerwonych tulipanów - rozpoznawalnym na całym świecie symbolem schorzenia. Optymizmem napawa także znajdujące się na niej zdjęcie Krystyny Baranowicz, zrobione na Filipinach w 2018 roku, na którym autorka zjeżdża kolejką tyrolską zawieszoną 150 metrów nad ziemią. Zdjęcie jest egzemplifikacją podejścia autorki do choroby - pomimo schorzenia Krystyna Baranowicz prowadzi aktywne życie.

Opracowanie jest warte polecenia także rodzinom i opiekunom osób z chorobą Parkinsona oraz profesjonalistom, którzy zajmują się pacjentami z tym rozpoznaniem, a więc lekarzom, rehabilitantom, fizjoterapeutom, psychologom, logopedom oraz studentom kierunków medycznych, psychologii czy logopedii. Książeczka pozwala lepiej zrozumieć chorych, odczytać ich potrzeby, poznać oczekiwania wobec specjalistów. Na własnym przykładzie autorka pokazuje, że pomimo choroby możliwe jest czynne, ciekawe, pełne pasji życie, że osoby chorej nie można postrzegać wyłącznie w kontekście jej ograniczeń i trudności. Krystyna Baranowicz przypomina, że do lekarza czy terapeuty zgłasza się nie tyle pacjent, ile po prostu drugi człowiek. Trzeba pamiętać, że zabiegi medyczne, usprawnianie fizyczne, terapia farmakologiczna czy logopedyczna są jedynie środkami prowadzącymi do poprawy jakości życia. $\mathrm{Z}$ osobistego doświadczenia autorka wie, jak ważne jest znalezienie specjalisty, który nie tylko zaordynuje leki czy ćwiczenia, ale także wykaże się wrażliwością, empatią i otwartością na innych. Oprócz tego „[...] w relacjach pacjent - lekarz bardzo ważne jest, czy nadają na tej samej fali, czy czują tego samego bluesa" (s. 10). Jest to jasna wskazówka dla pacjentów: szukajcie odpowiedniego dla was specjalisty, a także przesłanie dla specjalistów: słuchajcie uważnie pacjentów, to nie są kolejne przypadki, tylko konkretni ludzie. Przesłanie książki to także przypomnienie, że we wszystkich zawodach pomocowych istotna jest relacja $\mathrm{z}$ drugim człowiekiem.

Krystyna Baranowicz jest pedagogiem, emerytowanym profesorem Uniwersytetu Łódzkiego. W kręgu jej zainteresowań zawodowych znajdowała się edukacja włączająca i takie właśnie „włączające” podejście widoczne jest w każdym z rozdziałów. W tym przypadku inkluzja dotyczy włączania osób z chorobą Parkinsona do społeczności ludzi zdrowych, uwzględnienia różnorodności, odmienności, przezwyciężenia sposobu myślenia i postępowania opartego na wykluczeniu, a często samowykluczeniu.

Licząca 36 stron książeczka składa się z siedmiu rozdziałów autorstwa Krystyny Baranowicz oraz jednego opracowanego przez Dorotę Celińską-Mitaj. Poza tym 
w publikacji znalazł się wywiad z autorką (przeprowadzony także przez D. Celińską-Mitaj), osobisty wpis jej siostrzeńca (pod jakże wymownym tytułem Crazy woman), a także hymn i wiersz Jacka Norberta, prezesa Stowarzyszenia Osób z Chorobą Parkinsona i Ich Rodzin „Słonik” w Łodzi. Napisane z humorem i dystansem do własnej osoby opracowanie zawiera rzetelne i poparte fachową lekturą podstawowe informacje na temat schorzenia, a jednocześnie pochodzące „z pierwszej ręki” wskazówki, „jak żyć z Parkinsonem" (s. 4).

Tytuły poszczególnych rozdziałów w sposób jednoznaczny i precyzyjny oddają ich treść. Rozdział Oblubienica Parkinsona (jedna z wielu) - relacja świadka został napisany przez Dorotę Celińską-Mitaj - długoletnią przyjaciółkę Krystyny Baranowicz, która towarzyszyła zmaganiom autorki od momentu pojawienia się pierwszych symptomów choroby, poprzez długotrwały proces diagnozowania oraz poszukiwania skutecznych metod terapeutycznych. W rozdziale Jak to się zaczęło Krystyna Baranowicz powraca do chwili pojawienia się pierwszych niepokojących objawów, z perspektywy pacjentki opisuje doświadczenia związane z rozpoznaniem choroby i znalezieniem „odpowiedniego" lekarza. Rozdział zatytułowany Co to znaczy mieć Parkinsona poświęca krótkiej charakterystyce schorzenia. Autorka w przejrzysty sposób prezentuje teorie na temat etiologii choroby, opisuje jej symptomy, dzieli się uwagami na temat stosowanych powszechnie leków i ich skutków ubocznych, otwarcie i bardzo szczerze pisze o problemach, z którymi borykają się chorzy. W kolejnych dwóch rozdziałach przedstawia publikacje, $\mathrm{z}$ których pacjenci i ich rodziny mogą czerpać wiedzę na temat schorzenia, a także wymienia znane osoby z chorobą Parkinsona. Rozdział Wejście w nowe środowisko jest poświęcony działalności Stowarzyszenia Osób z Chorobą Parkinsona i Ich Rodzin Słonik. Stowarzyszenie organizuje spotkania towarzyskie, ale także zajęcia rehabilitacyjne, logopedyczne i taneczne - odgrywa ważną rolę integrującą pacjentów. W ostatnim rozdziale Dlaczego mimo początkowego oporu zgodziłam się na DBS można znaleźć informacje na temat nowych terapii w leczeniu osób z chorobą Parkinsona, w tym głębokiej stymulacji mózgu (Deep Brain Stimulation - DBS). Metoda polega na wszczepieniu cienkich elektrod, które generują impulsy modyfikujące funkcjonowanie części mózgu odpowiadających za rozwój choroby. Autorka przeszła zabieg w październiku 2019 roku. W rozdziale dzieli się osobistymi przeżyciami, opisuje przygotowania do operacji, sam jej przebieg, a także dokonuje oceny skuteczności zastosowanej terapii. Bezpośrednia relacja osoby, która poddała się zabiegowi, jest bezcenna dla rozważających możliwość skorzystania z tej formy leczenia.

Publikacja autorstwa Krystyny Baranowicz to lektura obowiązkowa dla pacjentów i ich rodzin, a także interesująca pozycja dla specjalistów. 
Literatura

Brabenec L., Mekyska J., Galaz Z., Rektorova I., 2017, Speech disorders in Parkinson's disease: early diagnostics and effects of medication and brain stimulation, „Journal of Neural Transmission”, no. 124, s. 303-334.

Dutkiewicz J., Friedman A., 2020, Diagnostyka zaburzeń autonomicznych $w$ chorobie Parkinsona, „Wiadomości Lekarskie”, nr 73, s. 809-813.

Gatkowska I., 2012, Diagnoza dyzartrii u dorosłych w neurologii klinicznej, Kraków: Wydawnictwo Uniwersytetu Jagiellońskiego.

Poewe W., 2008, Non-motor symptoms in Parkinson's disease, „European Journal Neurology”, April 15, suppl. 1, s. 14-20.

Wang C.-M., Tsai T.-T., Wang S.-H., Wu Y.-R., 2020, Does the M.D. Anderson Dysphagia Inventory correlate with dysphagia-limit and the Unified Parkinson Disease Rating Scale in early-stage Parkinson's disease?, "Journal of the Formosan Medical Association”, vol. 119, issue 1, part 2, s. 247-253.

\begin{tabular}{|l|l|}
\hline \multirow{2}{*}{ CC } & $\begin{array}{l}\text { C by the author, licensee Łódź University - Łódź University Press, Łódź, Poland. } \\
\text { This article is an open access article distributed under the terms and conditions } \\
\text { of the Creative Commons Attribution license CC-BY-NC-ND } 4.0 \\
\text { (https://creativecommons.org/licenses/by-nc-nd/4.0/) }\end{array}$ \\
\cline { 2 - 2 } & Data złożenia: 4.05.2021. Data przyjęcia: 24.05.2021. \\
\hline
\end{tabular}

